AMERICAN JOURNAL OF SCIENTIFIC AND INDUSTRIAL RESEARCH

(C) 2013, Science Huß, http://www.scihub.org/AJSIR

ISSN: 2153-649X, doi:10.5251/ajsir.2013.4.2.183.190

\title{
Purification and Characterization of $\alpha$ and $\beta$ - Amylases Isolated from Millet ( Pennisetum glaucum ) Malt
}

\author{
Mawahib E.M.El Nour ${ }^{1}$ and Sanaa O. Yagoub ${ }^{2}$ Ahmed Al Jarbough ${ }^{2}$ \\ 1- Department of Biology, Faculty of Science \&Technology, University of Al Neelain , P.O.Box \\ 12702, Khartoum, Sudan. \\ 2-Department of Pharmaceutics, Faculty of Pharmacy, Qassim University. Saudi Arabia.
}

\begin{abstract}
:
The work aimed to study the diastatic power (PD) of millet malt, to purify the $\alpha$ and $\beta-$ amylases and to characterize these enzymes. In this study the amylolytic activity initiated during the germination of millet was determined. Fourth day of germination of millet grains showed the highest of the amount of diastatic power (DP) (54.00 IOB), no significant variation $(P \leq 0.05)$ between the extraction procedures followed either by distilled water or water with $2 \%$ peptone. DEAE-cellulose chromatography was used for the partial purification of $\alpha$-and $\beta$ - amylases. The results obtained from the last purification steps is 6.50 fold of $\alpha$-amylase in fifth day of germination, whereas $\beta$-amylase is 37.50 fold in fourth day of germination. These amylases isolated from millet malt have interesting characteristics such as, storage stability of purified $\alpha$ and $\beta$ - amylases at different temperature $\left(-20\right.$ and $\left.4^{\circ} \mathrm{C}\right)$ for 56 days. No significant loss $(P \leq 0.05)$ in the enzymes activity during the storage period for 56 days in $-20^{\circ} \mathrm{C}$, whereas the loss of enzyme activity at $4^{\circ} \mathrm{C}$ during the period of 56 days were $28 \%$ for $\alpha$ and $35 \%$ for $\beta$-amylases. The maximum activity of $\alpha$-amylase was obtained at temperature $70^{\circ} \mathrm{C}$ and $50^{\circ} \mathrm{C}$ for $\beta$ amylase, it was clear that the $\alpha$-amylase is more stable than $\beta$-amylase. The optimum $\mathrm{pH}$ for both $\alpha$ and $\beta$ - amylases were 5.0 and 5.5 respectively. Therefore, these characterizations meet the prerequisites need for food industry. This work contributed with the advances in biotechnology generating of conditions for application of a new and of low price amylases source.
\end{abstract}

Key words : Diastatic power, $\alpha$ and $\beta$-amylases, millet malt, storage stability, enzymes temperature $\& \mathrm{pH}$.

\section{INTRODUCTION:}

The cereals are main food and considered as sources of energy, protein, vitamins and minerals for poor people in Sudan and some other African countries. Amylases are useful in abroad range of industrial application which includes food fermentation, textile and paper industries. $\alpha$ amylases ubiquitous in nature have been isolated, purified and characterized from a number of animal, plant, fungal as well as bacterial sources (Kumar et al., 2009).

The diastatic power (DP) refers to the total saccarifying power activity, which is considered as contribution of $\alpha$ and $\beta$ - amylases as well as $\alpha$ glucosidases which convert maltose to glucose (
Bureng and Worgan,1982). The thermostability of the DP enzymes is critical in determining fermentable sugar yield during mashing, where the mash temperature profile is a balance between the temperature required for starch gelatinization to enable efficient hydrolysis and the rate of thermal inactivation of the DP enzymes (Evan et al. ,2003 ). Zhang et al.(2006) showed that the variation in $\beta$ amylase activity was mainly attributable to the environment, although the effect of cultivar was also highly significant.

Etim and Etokkpan(1992) reported that diastatic activity of three sweet potato varieties was principally due to $\beta$-amylase. According to Omemu et al. ( 2005) the crude amylase preparation of A.niger AMO7 had temperature and $\mathrm{pH}$ optima activities at $60^{\circ} \mathrm{C}$ and 4.0 $\mathrm{pH}$ respectively. Muralikrishna \& Nirmala (2005) found that $\alpha$-amylases are more stable compared to 
$\beta$-amylases. EINour \& Yagoup (2010) reported that the fourth day of germination of sorghum showed the highest amount of $\alpha$ and $\beta$-amylase activity and decreased in fifth day of germination. Nirmala\& Muralikrishna (2003) revailed that the optimum $\mathrm{pH}$ ranged between 5.0-5.5 and temperature 45-50 for finger millet germinated for $72 \mathrm{~h}$. Egwin and Oloyede (2006) found that the maximum $\alpha$-amylase yield was attained from 72-120 hours of sprouting cereals and the optimum temperature for $\alpha$-amylase activity for sorghum malt was $70^{\circ} \mathrm{C}$. Maize malt characterization showed that $\alpha$ and $\beta$-amylase had optimal $\mathrm{pH}$ between 4-6.5, optimal temperature 50 and $90^{\circ} \mathrm{C}$ respectively (Biazus et al.2009). On the other hand Nagai et al. (2009) reported optimum $\mathrm{pH}$ of $\alpha$ amylase as $6.0-7.0$ and optimum temperature $40^{\circ} \mathrm{C}$ and the enzyme was extremely inactivated at $\mathrm{pH}$ higher than 7.0 or lower than 5.0. The heat inactivation occurred at more than $40^{\circ} \mathrm{C}$.

Mohamed et al.(2009) reported that the activity of $\alpha$ amylases increased from day 0 to 6 of germination of Triticum estivum a local Saudi Arabia wheat variety (Balady). Evans and Monday, (2009)found that the rate of $\alpha$-amylase secretion in sprouting maize, acha, rice and sorghum for $180 \mathrm{~h}$ is significantly high ( $P \leq 0.05)$ with growth period.

Different amylases give rise to oligosaccharides with specific lengths of glucose as major products, for this reasons different types of amylases, with unique properties are isolated and characterized for various application in the starch industry (Egwim and Oloyede, 2006).

The objectives of this research are to study the effects of malting and peptone addition on development of amylolytic activities in millet (Pennisetum glaucum L.) malt. Purification of $\alpha$ and $\beta$-amylases isolated from millet ((Pennisetum glaucum L.) malt, and characterization of purified $\alpha$ and $\beta$-amylases such as storage stability, the optimum temperature and $\mathrm{pH}$.

\section{MATERIALS AND METHODS}

This study was applied in Khartoum University, Faculty of Science, Department of Botany, from 2005-2008 as continuation for the data collected for the $\mathrm{PhD}$ of the first author.

\section{Materials:}

Millet malt: Millet ( Pennisetum glaucum L.) grains were purchased from local market. $500 \mathrm{~g}$ of millet was cleaned and freed from other materials and soaked in water overnight. The grains were spreaded on clean sack made from jute in plastic trays and covered by another jute sack and sprayed with water twice per day at temperature $28 \pm 2^{\circ} \mathrm{C}$ from 1-5 days. Germinated grains were left to dry by the air then ground using an electric grinder, which was operated intermittently so as to avoid heating. The powders were kept in glass bottles for chemical analyses. Three replicates for each experiment were used.

Measurement of diastatic power (DP) of millet grains and malt : Five gm of dry, fine powdered sample were taken in a conical flask containing 100 $\mathrm{ml}$ distilled water or $100 \mathrm{ml}$ of $2 \%$ peptone solution. The diastatic activity during the period of germination of millet grains was determined by the method of EBC (1987).

\section{Purification and characterization of $\alpha$-amylase isolated from millet malt}

Extraction of $\alpha$-amylase: The purification and characterization of $\alpha$-amylase isolated from millet malt was done according to the method of Botes et al(1967a). In order to extract the enzyme, eighty gm of millet malt were suspended in $300 \mathrm{ml}$ of cooled distilled water using cooled warring blender. The suspension was stirred continuously over night at low temperature $\left(4^{0} \mathrm{C}\right)$ and then centrifuged at $14,000 \mathrm{~g}$ for 20 minutes.

Purification of millet malt $\alpha$ - amylase: Crude $\alpha$ amylase was prepared by extracting as described above .The clear extract was $40 \%$ saturated with solid ammonium sulphate which precipitated the $\alpha-$ amylase. The precipitate was allowed to settle over night, collected by centrifugation, dialyzed to remove the salts and then freeze dried. The supernatant which contained the $\beta$-amylase was used for the preparation of $\beta$-amylase.

Fifteen grams of the crude $\alpha$-amylase were dissolved in $1500 \mathrm{ml} 0.1 \mathrm{M}$ acetate buffer (pH5.9) containing $0.2 \%$ calcium acetate and $60 \mathrm{~g}$ decolorizing charcoal was added. The mixture was heated at $70^{\circ} \mathrm{C}$ for 15 min with stirring. The suspension was cooled to $4^{\circ} \mathrm{C}$ and the charcoal and coagulated protein removed with sold ammonium sulphate, the precipitate which formed collected by centrifugation, dissolved in $0.1 \mathrm{M}$ tris buffer $\mathrm{pH} 7.0+0.2 \% \mathrm{CaAc}$ and dialyzed overnight against the same buffer.

The dialyzed solution from the previous step was applied to $4 \times 12 \mathrm{~cm}$ DEAE cellulose column. The column was first eluted with $0.1 \mathrm{M}$ tris buffer $\mathrm{pH}$ $7.0+0.2 \% \mathrm{CaAc}$ and the eluate discarded. This was 
followed by elution with $0.1 \mathrm{M}$ tris buffer $\mathrm{pH} 7.0+0.3$ $\mathrm{Nacl}+0.2 \mathrm{CaAc}$ in which the bulk of the activity appeared.

Enzyme assay ( $\alpha$ \& $\beta$-amylase):Soluble starch (Merck, special for diastatic power determination) was used as substrate for $\alpha$ and $\beta$-amylase activity. Apparent saccharifying power was estimated from the amount of reducing sugars, calculated as maltose produced from $2 \mathrm{ml}$ of $2 \%$ starch solution in $0.05 \mathrm{M}$ acetate buffer of $\mathrm{pH} 4.6$, when treated with $0.1 \mathrm{ml}$ of suitable diluted enzyme solution for $10 \mathrm{~min}$ at $30^{\circ} \mathrm{C}$. The enzyme reaction was stopped by adding $2 \mathrm{ml}$ of 3,5-dinitrosalicylic acid reagent used for the determination of reducing sugars.

\section{Purification and characterization of $\beta$-amylase isolated from millet malt:}

Purification steps of millet malt $\beta$-amylase: The purification of $\beta$-amylase as described by (Botes et al., 1967b) was followed. The supernatant obtained after precipitation of $\alpha$-amylase at $40 \%$ saturation with ammonium sulphate, contained the $\beta$-amylase. The supernatant was precipitated with $70 \%$ ammonium sulphate. The precipitate was allowed to settle overnight collected by centrifugation, dialyzed to remove the salts and freeze-dried.

Twenty grams of the crude $\beta$-amylase were dissolved at room temperature in $2000 \mathrm{ml} 0.1 \%$ cysteine $(\mathrm{pH}$ 6.0) containing $0.2 \%$ EDTA. The $\mathrm{pH}$ of the solution was lowered to 3.2 by addition of $5.0 \mathrm{~N}$ acetic acid and the solution was kept at this $\mathrm{pH}$ for one hour at room temperature. The $\mathrm{pH}$ of the solution was then adjusted to 4.6 by the addition of solid sodium acetate.

The solution was cooled to $-2^{\circ} \mathrm{C}$ and fractionated with ethanol at -10 to- $12^{\circ} \mathrm{C}$. The precipitate obtained at an alcohol concentration between 33.33 and $66.66 \% \mathrm{v} / \mathrm{v}$ contained in a refrigerated centrifuge. The precipitate was dissolved in chilled $0.05 \mathrm{M}$ acetate buffer of $\mathrm{pH}$ 5.0 and dialyzed overnight against the same buffer.

The dialyzed solution was applied to a $4 \times 8 \mathrm{~cm}$ DEAEcellulose column. The column was first eluted with $0.05 \mathrm{M}$ acetate buffer of $\mathrm{pH} 5.0$ and the eluate discarded. This was followed by elution with $0.15 \mathrm{M}$ acetate buffer of $\mathrm{pH} 5.0$ which resulted into two partly separated elution peaks. $\beta$-amylase activity was associated only with the last peak. Those fractions which contained the enzyme were combined, 90\% saturated with solid ammonium sulphate, and the precipitate was collected by centrifugation.
Protein determination:Protein was quantified by the method of Bradford (1976) with bovine serum albumin as standard.

Storage stability of $\alpha$ and $\beta$-amylases:Twenty fractions of $0.1 \mathrm{ml}$ from purified enzyme preparations were taken in 20 test tubes. Ten of these tubes were stored in a refrigerator at $4^{\circ} \mathrm{C}$, the other were placed in a freezer at $-20^{\circ} \mathrm{C}$. The enzyme activity were assayed with 7 days interval for both the frozen enzyme preparations and the enzyme stored at $4^{\circ} \mathrm{C}$. The decrease in the absorbance values was measured and the percent of remaining activity was calculated.

Effect of temperature and $\mathrm{pH}$ on the $\alpha$ and $\beta$ amylase activity: The optimum temperature of $\alpha$ and $\beta$-amylases was determined using different temperatures for enzymes reaction $(30.40,50,60,70$ and $80^{\circ} \mathrm{C}$ ). The enzymes activity was assayed for each temperature reaction at $\mathrm{pH} 4.6$ and 5.0 for $\alpha$ and $\beta$-amylases respectively, for 10 minutes. The optimum $\mathrm{pH}$ values of $\alpha$ and $\beta$-amylases for the reaction mixture was determined using acetate buffer at different $\mathrm{pH}$ values $(2.0,4.0,5.0 .6 .0,7.0,8.0$, and 9.0). The enzymes activity was measured at each $\mathrm{pH}$ value at $30^{\circ} \mathrm{C}$ for 10 minutes.

\section{RESULTS AND DISCUSSION:}

\section{Diastatic power (DP):}

During the process of germination, it was clear that DP was started by the onset of germination from the I th day and continued until it reached the maximum value at the $4^{\text {th }}$ day of germination as 54.0 IOB. Then it decreased on the $5^{\text {th }}$ day (fig 1 ). These results agree with that obtained by Etim and Etokkpan (1992) who reported that diastatic activity of three potato varieties was principally due to $\beta$-amylase. Also the purification of $\beta$-amylase in this study revealed that the fourth day of germination of millet showed the highest amount of enzyme activity and decreased in the fifth day of germination, these results also confirmed by Egwin \& Oloyede (2006) and EINour \&Yagoup (2010). The results showed that the values of amylolytic activity slightly lower than that obtained from sorghum malt (EINour\&Yagoup,2010) . Figure(1) also showed that there was no significant variation $(p \leq 0.05)$ between the extraction procedures followed either by distilled water or distilled water with $2 \%$ peptone. 


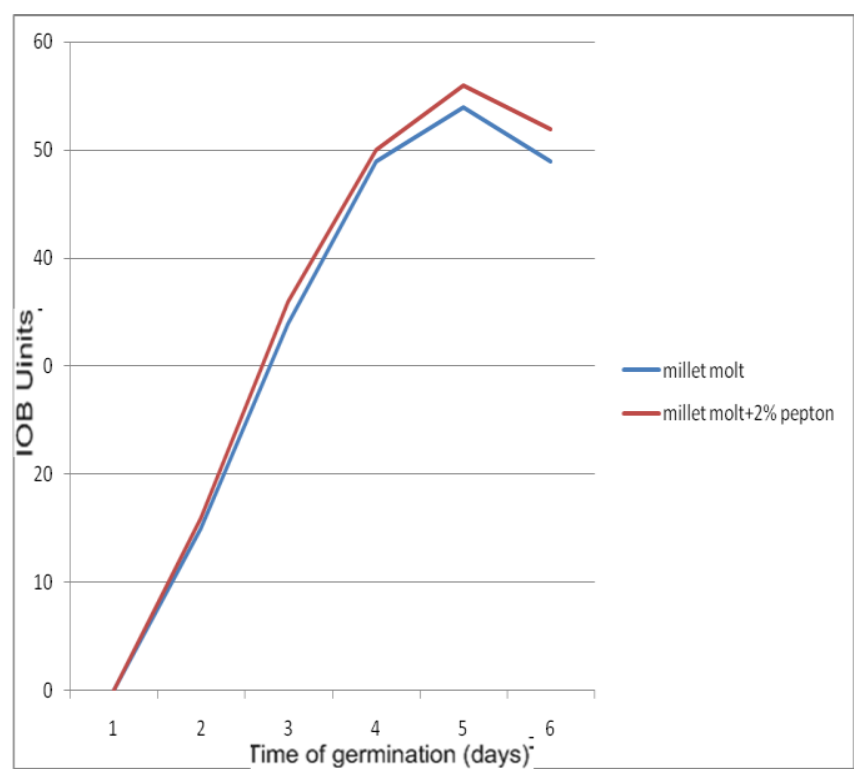

Fig (1): Comparative development of diastatic power (DP) in Pennisetum glaucum malt

Purification of $\alpha$ and $\beta$ - amylase:

represented the results of the purification steps of $\boldsymbol{\alpha}$ amylase. Heating the crude enzyme for $15 \mathrm{~min}$. at $70^{\circ} \mathrm{C}$ increased the specific activity of millet malt from one to five days by $1.65,2.06,2.73,2.79$ and 2.90 folds. At the same time the total protein decreased by $53 \%, 57 \%, 72 \%, 75 \%$ and $76 \%$ in the same order as compared by the initial value. The values of enzyme yield were $76 \%, 88 \%, 75 \%, 77 \%$ and $72 \%$. It is clear that heat step of purification is successful step, this result supported the findings of Kumar et al. (2005) and Egwin \& Oloyede (2006).The results using DEAE-cellulose chromatography indicated that the purification folds were 5.40 and 6.50 for $4^{\text {th }}$ and $5^{\text {th }}$ day of germination, respectively. The total protein were reduced by $86 \%$ and $89 \%$ of the initial values.
At the same time the yields of the enzymic activity were $74 \%$ and $70 \%$ of the starting value. Purification steps of $\boldsymbol{\beta}$ - amylase was summarized in table (2). The bulk of $\boldsymbol{\beta}$-amylase was precipitated at an acid treatment and an alcohol fractionation. The specific activity was increased by $9.25,10.30,17.4,24.67$ fold at day 1,2,3,4 respectively, and then decreased to 12.96 at the $5^{\text {th }}$ day of germination compared to initial value. At the same time the total protein were decreased by $92 \%, 92 \%, 95 \%, 96 \%$ and $93 \%$ respectively. The enzyme yields were $78 \%$, $80 \%, 81 \%, 82 \%$ and $80 \%$ respectively. Botes et al.(1967b) reported that the acid treatment reduced $\alpha$-amylase while the $\beta$-amylase activity remained constant then alcohol fractionation removed the last traces of $\alpha$-amylase and gave considerable purification of $\beta$-amylase. In this study it was clear that high purification fold (37.57) was obtained during the $4^{\text {th }}$ day of germination, where DEAE -cellulose chromatography was used, these might confirm Botes et al.(1967b) results. The total protein was reduced by $98 \%$.and the yield of enzyme activity was $75 \%$ compared to initial value. At the same time during the fifth day of germination the specific activity was reduced in all steps of purification treatment.

The storage stability of purified $\alpha$ and $\beta$-amylases at $20^{\circ} \mathrm{C}$ and $4^{\circ} \mathrm{C}$ for 56 days was determined. It was observed that there was no significant loss in the enzymes activity during the storage period for 56 days in $-20^{\circ} \mathrm{C}$ for both enzymes isolated from millet malt. The loss of activity at $4^{\circ} \mathrm{C}$ during the period of 56 days was $25 \%$ for $\alpha$, whereas the loss of $\beta$ amylase activity during storage period at $4{ }^{\circ} \mathrm{C}$ at days 35, 42, 49 and 56 were 21, 26, 31 and 35\% (Fig 2). Theses results confirm the findings of Muralikrishna and Nirmala( 2005), who observed that $\alpha$-amylases are more stable compared to $\beta$-amylase. 
Am. J. Sci. Ind. Res., 2013, 4(2): 183-190

Table (1) Purification steps of $\alpha$ - amylase isolated from millet (Pennisetum glaucum ) germinated for five days.

\begin{tabular}{|c|c|c|c|c|c|c|c|c|}
\hline Days & Step of purification & $\begin{array}{l}\text { Total } \\
\text { Vol.(m } \\
\text { l) }\end{array}$ & 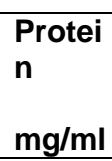 & $\begin{array}{l}\text { Total } \\
\text { protein } \\
(\mathrm{mg})\end{array}$ & $\begin{array}{l}\text { Enz.spec.Act.U/ } \\
\text { mg } \\
\text { prot. }\end{array}$ & $\begin{array}{c}\text { Total } \\
\text { enz.activity } \\
\text { units }\end{array}$ & $\begin{array}{l}\text { Yiel } \\
\text { ds } \\
\%\end{array}$ & $\begin{array}{l}\text { Purific } \\
\text { ation } \\
\text { fold }\end{array}$ \\
\hline \multirow{3}{*}{ Day 1} & Crude J $\alpha$ amylase & 78.0 & 5.30 & 413.4 & $80 \pm 0.53$ & 33263.6 & 100 & - \\
\hline & $\begin{array}{l}40 \%\left(\mathrm{NH}_{4}\right)_{2} 2 \mathrm{SO}_{4} \\
\text { fractionation }\end{array}$ & 56.0 & 4.70 & 263.2 & $118.1 \pm 0.90$ & 31101.2 & 93 & 1.46 \\
\hline & $\begin{array}{l}\text { Heat at } 70^{\circ} \mathrm{C} \text { for } 15 \\
\text { mins. }\end{array}$ & 49.0 & $3 . .90$ & 191.1 & $1326 \pm 0.72$ & 25413.4 & 76 & 1.65 \\
\hline \multirow{3}{*}{ Day 2} & Crude J $\alpha$ amylase & 76.0 & $5 . .50$ & 418 & $90.12 \pm 0.11$ & 37666.5 & 100 & - \\
\hline & $\begin{array}{l}40 \%\left(\mathrm{NH}_{4}\right)_{2} 2 \mathrm{SO}_{4} \\
\text { fractionation }\end{array}$ & 48.0 & 4.45 & 213.6 & $161.6 \pm .0 .42$ & 34528.3 & 91 & 1.79 \\
\hline & $\begin{array}{l}\text { Heat at } 70^{\circ} \mathrm{C} \text { for } 15 \\
\text { mins. }\end{array}$ & 42.0 & 4.27 & 179.3 & $185.5 \pm .0 .51$ & 33279.4 & 88 & 2.06 \\
\hline \multirow[t]{3}{*}{ Day3 } & Crude J $\alpha$ amylase & 75.0. & 5.72 & 429.3 & $114.5 \pm 0.7$ & 49177.3 & 100 & - \\
\hline & $\begin{array}{l}40 \%\left(\mathrm{NH}_{4}\right)_{2} \mathrm{SO}_{4} \\
\text { fractionation }\end{array}$ & 49.0 & 4.24 & 206.4 & $193.3 \pm 0.76$ & 39890.9 & 81 & 1.68 \\
\hline & $\begin{array}{l}\text { Heat at } 70^{\circ} \mathrm{C} \text { for } 15 \\
\text { mins. }\end{array}$ & 30,0 & 3.94 & 118.2 & $313.3 \pm 0.34$ & 37040.9 & 75 & 2.73 \\
\hline \multirow{4}{*}{ Day4 } & Crude J $\alpha$ amylase & 72.0 & 6.5 & 466.6 & $164.3 \pm 0.06$ & 76672.7 & 100 & - \\
\hline & $\begin{array}{l}40 \%\left(\mathrm{NH}_{4}\right)_{2} \mathrm{SO}_{4} \\
\text { fractionation }\end{array}$ & 50.0 & 4.32 & 216.0 & $298.0 \pm 0.03$ & .64372 .9 & 84 & 1.80 \\
\hline & $\begin{array}{r}\text { Heat at } 70^{\circ} \mathrm{C} \text { for } 15 \\
\text { mins. }\end{array}$ & 50.0 & 4.32 & 216.0 & $298.0 \pm 0.03$ & 64372.9 & 77 & 2.79 \\
\hline & $\begin{array}{l}\text { DEA-cellulo } \\
\text { chromatography }\end{array}$ & 33.0 & 1,94 & 64.15 & $888.7 \pm 0.3$ & 59346.7 & 74 & 5.4 \\
\hline \multirow{4}{*}{ Day 5} & Crude Ja amylase & 73.0 & 6.50 & 474.5 & $141.8 \pm 0.22$ & 67300.8 & 100 & - \\
\hline & $\begin{array}{l}40 \%\left(\mathrm{NH}_{4}\right)_{2} \mathrm{SO}_{4} \\
\text { fractionation }\end{array}$ & 40.0 & 5.10 & 204 & $250.9 \pm 0.6$ & 51181.3 & 76 & 1.76 \\
\hline & $\begin{array}{l}\text { Heat at } 70^{\circ} \mathrm{C} \text { for } 15 \\
\text { mins. }\end{array}$ & 27.0 & 4.32 & 116.6 & $415.9 \pm 0.31$ & 48518.9 & 72 & $9 j 2$ \\
\hline & $\begin{array}{l}\text { DEA-cellulo } \\
\text { chromatography }\end{array}$ & 23.0 & 2.25 & 51.75 & $918.7 \pm 0.42$ & 47541.2 & 70 & 6.5 \\
\hline
\end{tabular}


Am. J. Sci. Ind. Res., 2013, 4(2): 183-190

Table (2) Purification steps of $\beta$-amylase isolated from millet (Pennisetum glaucum L.) germinated for five days

\begin{tabular}{|c|c|c|c|c|c|c|c|c|}
\hline Days & Step of purification & $\begin{array}{l}\text { Total } \\
\text { Vol.(m } \\
\text { I) }\end{array}$ & $\begin{array}{l}\text { Protein } \\
\mathrm{mg} / \mathrm{ml}\end{array}$ & $\begin{array}{r}\text { Total } \\
\text { protein } \\
(\mathrm{mg})\end{array}$ & $\begin{array}{l}\text { Enz.spec.Act.U } \\
\text { /mg prot. }\end{array}$ & $\begin{array}{l}\text { Total } \\
\text { enz.activity } \\
\text { units }\end{array}$ & $\begin{array}{l}\text { Yield } \\
\text { s } \\
\%\end{array}$ & $\begin{array}{r}\begin{array}{r}\text { Purification } \\
\text { fold }\end{array}\end{array}$ \\
\hline \multirow{3}{*}{ Day 1} & Crude $\beta$ amylase & 83.0 & 5.0 & 415.00 & $0.218 \pm 0.01$ & 90.545 & 100 & - \\
\hline & $\begin{array}{l}70 \%\left(\mathrm{NH}_{4}\right)_{2} \mathrm{SO}_{4} \\
\text { fractionation }\end{array}$ & 15.0 & 4.70 & 70.50 & $1.036 \pm 0.08$ & 73.063 & 80 & 4.75 \\
\hline & $\begin{array}{l}\text { Acid treatment\& alcohol } \\
\text { fractionation }\end{array}$ & 11.0 & 3.20 & 35.20 & $2.018 \pm 0.16$ & 71.040 & 78 & 9.25 \\
\hline \multirow{3}{*}{ Day 2} & Crude $\beta$ amylase & 87.0 & 5.21 & 453.0 & $0,327 \pm 0.01$ & 148.219 & 100 & _ \\
\hline & $\begin{array}{l}70 \%\left(\mathrm{NH}_{4}\right)_{2} \mathrm{SO}_{4} \\
\text { fractionation }\end{array}$ & 17.0 & 4.39 & 74.6 & $1.745 \pm 0.04$ & 130.263 & 87 & 5.33 \\
\hline & $\begin{array}{l}\text { Acid treatment \&alcohol } \\
\text { fractionations. }\end{array}$ & 13.0 & 2.73 & 35.5 & $3.381 \pm 0.07$ & 120.020 & 80.0 & 10.3 \\
\hline \multirow{3}{*}{ Day 3} & Crude $\beta$ amylase & 80.0 & 5.40 & 432.0 & $0.818 \pm 0.00$ & 353.5 & 100 & - \\
\hline & $\begin{array}{l}\left.70 \% \mathrm{NH}_{4}\right)_{2} \mathrm{SO}_{4} \\
\text { fractionation }\end{array}$ & 14.0 & 4.20 & 58.0 & $5.345 \pm 0.02$ & 314.3 & 88 & 6.53 \\
\hline & $\begin{array}{l}\text { Acid treatment \&alcohol } \\
\text { fractionation. }\end{array}$ & 10.0 & 2.00 & 20.0 & $14.29 \pm 0.40$ & 285.80 & 81 & 17.4 \\
\hline \multirow{4}{*}{ Day 4} & Crude $\beta$ amylase & 80.0 & 5.70 & 459.0 & $1.309 \pm 0 . .00$ & 596.9 & 100 & - \\
\hline & $\begin{array}{l}70 \%\left(\mathrm{NH}_{4}\right)_{2} \mathrm{SO}_{4} \\
\text { fractionation }\end{array}$ & 12.0 & 4.60 & 55.2 & $9.212 \pm 0.06$ & 508.5 & 85 & 7.03 \\
\hline & $\begin{array}{l}\text { Acid treatment } \\
\text { \&alcohfractionation }\end{array}$ & 9.00 & 1.70 & 15.3 & $32.29 \pm 0.07$ & 494.1 & 82 & 24.67 \\
\hline & $\begin{array}{l}\text { DEAE-cellulose } \\
\text { chromatogr. }\end{array}$ & 6.00 & 1.52 & 9.12 & $49.13 \pm 0.17$ & 448.1 & 75 & 37.57 \\
\hline \multirow{3}{*}{ Day 5} & Crude $\beta$ amylase & 78.0 & 6.0 & 468.0 & $1.470 \pm 0.01$ & 689.0 & 100 & - \\
\hline & $\begin{array}{l}70 \%\left(\mathrm{NH}_{4}\right)_{2} \mathrm{SO}_{4} \\
\text { fractionation } \mathrm{n}\end{array}$ & 12.0 & 5.9 & 70.80 & $8.400 \pm 0.10$ & 594.70 & 86 & 5.70 \\
\hline & $\begin{array}{l}\text { Acid treatment \&alcohol } \\
\text { fractionation }\end{array}$ & 10.0 & 2.90 & 29.00 & $19.1 \pm 0.50$ & 553.60 & 80 & 12.96 \\
\hline
\end{tabular}

torage stability of $\alpha$ and $\beta$-amylases: 


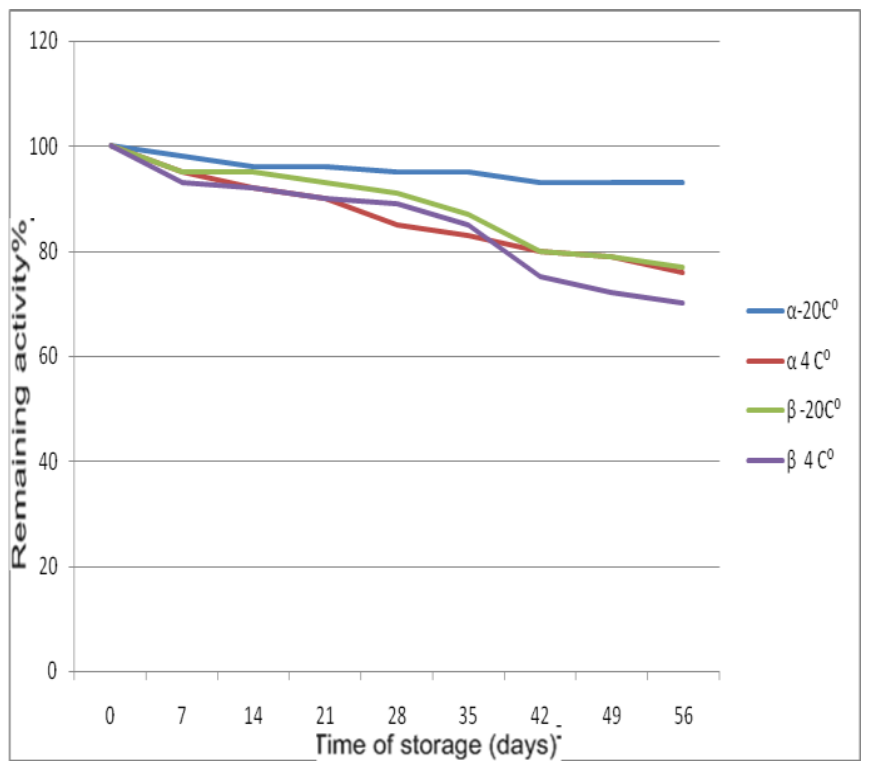

Fig(2) Pennisetum glaucum $\alpha$-and $\beta$-amylases stability at two different storage conditions.

\section{The effect of temperature and $\mathrm{pH}$ on $\alpha$ and $\beta$ - amylases:}

The influence of temperature on $\alpha$ and $\beta$ - amylases activity showed that enzyme activity increased progressively with increase in temperature from $30^{\circ} \mathrm{C}$ reaching a maximum at $70^{\circ} \mathrm{C}$ for $\alpha$-amylase and $50^{\circ} \mathrm{C}$ for $\beta$-amylase as shown in (fig 3 ). Above $70^{\circ} \mathrm{C}$ and $50^{\circ} \mathrm{C}$ there was a reduction in $\alpha$ and $\beta$-amylases activity respectively. These results agree with that reported by Egwin and Oloyede (2006), they found that the optimum temperature for $\alpha$-amylase activity isolated from sorghum malt was $70^{\circ} \mathrm{C}$. These results conversely with that obtained by Nirmala and Muralikrishna (2003), where the optimum temperature of $\alpha$-amylase isolated from finger millet ranged between $45-50^{\circ} \mathrm{C}$. The results showed that the activity of $\alpha$-amylase decreased markedly after being heated for 15 minute at temperature up to $70^{\circ} \mathrm{C}$ this agree with the findings of Bureng and worgan (1982). On the other hand, the $\beta$-amylase enzyme was stable at $50^{\circ} \mathrm{C}$ for 10 minutes; then the specific activity of enzyme reduced markedly as temperature above $50^{\circ} \mathrm{C}$.

The effect of $\mathrm{pH}$ on $\alpha$ and $\beta$-amylases activity isolated from sorghum malt was showed that the enzymes specific activity was reached a maximum value at $\mathrm{pH} 5.0$ and 5.5 respectively, (Fig 4). These results conversely with that obtained by (Egwin and
Oloyede. 2006). As the same time the obtained data agree with the finding of Nirmala and Muralikrishna (2003) who found that the optimum of $\mathrm{pH} \alpha$-amylases for finger millet was a range of 5.0-5.5. Mohamed et al. (2009) reported that the optima of different $\alpha$ amylases of wheat have broad $\mathrm{pH}$ optima range from 5.0 to 7.0. This $\mathrm{pH}$ finding of $\beta$-amylase agrees with that of Okon and Uwaifo (1984) who reported that the optimum $\mathrm{pH}$ of $\beta$-amylase was 5.5 .

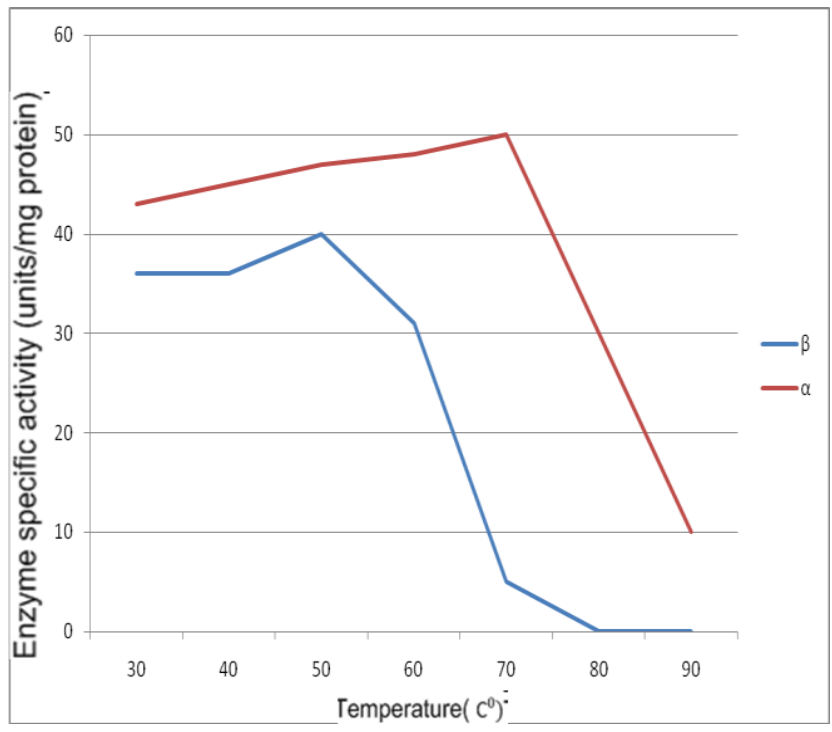

Fig (3) Temperature dependent activity profile of Pennisetum glaucum malt $\alpha$-and $\beta$-amylases

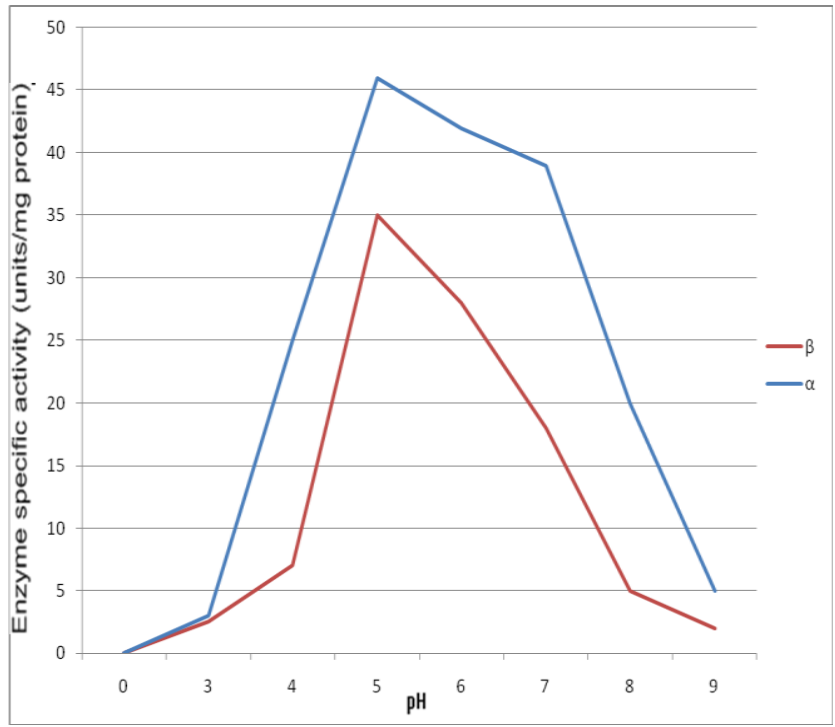

Fig (4) Pennisetum glaucum malt $\alpha$-and $\beta$-amylases activity as a function of $\mathrm{pH}$ at $30^{\circ} \mathrm{C}$ 


\section{REFERENCES:}

Biazus, J.P.M.,R.R.deSouza, E.M. Marquez, T.T. Franco, J.C.C. Santana and E. B.Tambourgi 2009. Production and Characterization of amylases from Zea mays malt. Braz. Arch. Boil. Technol. 52(4). DOI:10.1590/S151689132009000400024

Botes, D.P., F.J. Joubert, and L. Novellie ,1967a. Kaffircorn malting and brewing studies XVIIPurification and properties of sorghum malt $\alpha$-amylase. J. Sci. Food Agric. 18: 409-414. DOI:10.1002/jsfa.2740180908

Botes, D.P., F.J. Joubert, and L. Novellie , 1967b. Kaffircorn malting and brewing studies XVIIPurification and properties of sorghum malt $\beta$-amylase. J. Sci. Food Agric. 18: 415-417. DOI 10.1002/jsfa.2740180909

Bradford, M. M., 1976. A rapid and sensitive method for the quantization of microgram quantities of protein utilizing the principle of protein- dye binding. Analyt. Biochem. 72: 248-254. DOI : 1021/bp 0340971

Bureng,P.L.and J. T. Worgan ,1982. Properties of amylases and $\alpha$-glucosidase in Feterita (Sorghum malt) Sudan J. Food Sci. and Techno. 14: 34-40. DOI : 10.1385/1-59259-765-3:283

EBC ( European Brewery Convention). Analytica EBC, 1987. EBC $4^{\text {th }}$ edition. 1:4-12. linkinghub.elsevier.com/retrieve/pii/S11610301030001 94

Egwin , E C. and O.B. Oloyede ,2006. Comparison of $\alpha$ amylase activity in some sprouting. Nigerian Cereal. Biokemistri,Vol. $\quad 18 \quad$ (1) pp15-20. http://www.bioline.org.br/pdf?bk06003

EINour, M. E. M. and S.O.Yagoup, 2010. Partial purification and characterization of $\alpha$ and $\beta$-amylases isolated from Sorghum bicolor cv(Feterita )malt. Journal of applied sciences.10 (13): 1314-1319.

Etim M.U. and O. U .EtokAkpan ,1992. Sorghum brewing using sweet potato enzymic flour to increase saccharification. World J.Microbiol. \& Biotechnol 8(5): 509-511. DOI: 10.1007/ BF01201950

Evans, C. E.and Monday, O. A. 2009. Prediction aamylase yield and malt quality of some sprouting cereals using $2^{\text {ed }}$ order polynomial model. Afric. J. of Bioch. 3(8): 288-292. http://www.academicjournals.org/ajbr/PDF

Evan, D.E. Van Weger B. Ma Y.F, Eghinton, J. 2003 . The impact of the thermostability of $\alpha$-amylase, $\beta$-amylase and limit dextrinase on potential work fermentability. J. Am. Society of Brewing Chem. 61: 210-218. DOI: 10.1094/ASBCJ-61-0210

Kumar,R.S.S., S. A.Singh and G. A. Rao, 2005. Thermal Stability of $\alpha$-amylase from Malted Jowar (Sorghum bicolor). J.Agric Food Chem. 53(17) pp 6883-6888 DOI: $10.1021 / \mathrm{jf0501701}$

Kumar R.S.S., S.A.Singh and G.A.Rao, 2009. Conformational Stability of a amylase from malted sorghum ( Sorghum bicolor ): reversible unfolding by denaturants. Biochemie.91: 548-557. http://www.ncbi.nlm.nih.gov/pubmed/19278621

Mohamed ,S.A., L. Abdulrahman, Al-Malki and T.A. Kumosani ,2009. Partial purification and characterization of five $\alpha$-amylase from a wheat I0cal variety (Balady) during germination. Australian J. of Basic and Applied Sci .3 : (3) 1740-1748. doi.wiley.com/10.1111/j.1745-4514.1981.tb00658.x

Muralikrishna, G.and M. Nirmala, 2005. Cereal $\alpha$-amylases an overview. Carbohhyd. Polm. 60: 163-173. www.idosi.org/wasj/wasj3(1)/17.pdf..

Nagai T, R. Inoue, N. Suruki and T. Nagashima 2009.Alpha-amylase from persimmon honey :Purification and characterization. International J.of food properties 12(3) 512-521.DOI: $10.1080 / 10942910701867764$

Nirmala ,.M. and G. Muralikrishna, 2003. Three- amylases from malted fingr millet (Ragi, Eleusine coracana, elndaf-15).Purification and partial characterization.. Phytochm. 62: 21-30 pubs.acs.org/doi/abs/10.1021/jf071918d

Okon, E.U. and Uwaifo, A, O. 1984. Partial purification and properties of $\beta$-amylases isolated from Sorghum bicolor (L.) Moench. J. Agric Food Chem. 37(1): 11-14. DOI: 10.1021/jf00121a003

Omemu ,A.M., Akpan , M. O.Bankole, and O.D.Teniola ,2005. Hydrolysis of raw tuber starches by amylases of Asperigillus niger AMO7 isolated from the soil. J. Biotech. 4(1) 19-25. https://tspace.library.utoronto.ca/bitstream/ $/ \overline{1807 / 6581 /}$ 1/jb05004.pdf

Zhang, G.P.,Chen, J.X. Dai J. M. Wang and F. B. Wu. 2006. The effect of cultivar and environment on $\beta$ amylase activity is associated with the change of protein content in barley grains. J. of Agron. and Crop Sci. 192: 43-49. doi.wiley.com/10.1111/j.1439037X.2006.00181.X 